\title{
Salivary leucocytes as suitable biomatrix for the comet assay in human biomonitoring studies
}

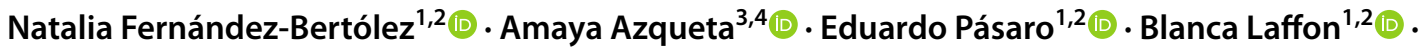 \\ Vanessa Valdiglesias ${ }^{2,5}$
}

Received: 23 February 2021 / Accepted: 25 March 2021 / Published online: 31 March 2021

(c) The Author(s), under exclusive licence to Springer-Verlag GmbH Germany, part of Springer Nature 2021

\begin{abstract}
Peripheral blood leucocytes (PBL) have been traditionally used to investigate DNA damage by the comet assay in population studies, but validating alternative non-invasive samples would expand the application of this assay in human biomonitoring. The objectives of this study were (i) to test the validity of salivary leucocytes as a proper biomatrix for the comet assay, (ii) to evaluate the ability of this approach to detect different types of primary and oxidative DNA damage, and (iii) to determine whether frozen salivary leucocytes are still suitable for displaying those types of DNA damage. Fresh and frozen leucocytes isolated from saliva samples (six healthy non-smoking volunteers), were exposed to four genotoxic agents inducing different types of DNA damage, both primary (methyl methanesulfonate, actinomycin-D, ultraviolet radiation) and oxidative (potassium bromate), and standard or enzyme-modified comet assay was conducted. Results were compared with those obtained from PBL. Cells exposed to the four genotoxic agents showed dose-dependent increases of primary and oxidative DNA damage, demonstrating the suitability of all these samples to detect genetic damage from different origin. When comparing baseline levels of DNA damage, just a slight significant increase in primary DNA damage was observed in frozen salivary leucocytes regarding the other biomatrices, but similar results were obtained regarding sensitivity to DNA damage induction by all agents tested. This study demonstrates that salivary leucocytes can be employed in comet assay as an alternative or complement to blood samples. Frozen salivary leucocytes were proved to be a very convenient sample in large biomonitoring studies.
\end{abstract}

Keywords Comet assay $\cdot$ Frozen samples $\cdot$ Human biomonitoring $\cdot$ Salivary leucocytes

Blanca Laffon and Vanessa Valdiglesias contributed equally to the senior authorship of this manuscript.

Blanca Laffon

blaffon@udc.es

1 Centro de Investigaciones Científicas Avanzadas (CICA), Departamento de Psicología, Facultad de Ciencias de la Educación, Universidade da Coruña, Grupo DICOMOSA, Campus Elviña s/n, 15071 A Coruña, Spain

2 Instituto de Investigación Biomédica de A Coruña (INIBIC), AE CICA-INIBIC, Oza, 15071 A Coruña, Spain

3 Department of Pharmacology and Toxicology, University of Navarra, c/ Irunlarrea 1, 31009 Pamplona, Spain

4 IdiSNA, Navarra Institute for Health Research, Pamplona, Spain

5 Centro de Investigaciones Científicas Avanzadas (CICA), Departamento de Biología, Facultad de Ciencias, Universidade da Coruña, Grupo DICOMOSA, Campus A Zapateira s/n, 15071 A Coruña, Spain

\section{Introduction}

The comet assay is a well-established, simple and sensitive method to measure DNA damage in single cells. It is commonly used in human population studies to investigate the effects of pollution, occupational hazards and potential genoprotective agents (Szeto et al. 2012), and in basic research to address the mechanisms of DNA damage and repair (Azqueta and Collins 2013). The standard alkaline version of the assay is able to detect primary genetic damage including DNA strand breaks, both single and double, alkali-labile sites-apurinic and apyrimidinic sites-, and delayed repair sites (Rojas et al. 1999). Moreover, the enzyme-modified version of the assay, incorporating a digestion of DNA with lesion-specific endonucleases, allows the measurement of oxidative DNA damage by converting the oxidised bases into breaks (Collins et al. 2014). 
The advantages of the comet assay relative to other genotoxicity tests include its sensitivity in detecting low levels of DNA damage, the requirement of a small number of cells per sample, and its flexibility, simplicity, ease of application, economy, and short duration (Collins 2004). An additional benefit of the comet assay for human biomonitoring is the feasibility of application to a broad spectrum of cells, including both proliferating and non-proliferating cells, as well as cells from tissues which are the first targets for the genotoxic insults (Rojas et al. 2014). Due to these advantages, the comet assay is frequently employed as DNA damage biomarker in molecular epidemiology studies, playing an important role in monitoring the effects of occupational and environmental hazardous agent such as pesticides, polycyclic aromatic hydrocarbons, heavy metals or ionizing radiation [reviewed in Collins et al. (2014)].

Peripheral blood leucocytes (PBL), isolated from whole blood, are the most common cell type used for this assay (gold standard) in human population studies, but collection of whole blood samples involves an invasive procedure and requires participation of a professional health carer, since finger prick samples can only be used for yielding a small number of comets. Moreover, venepuncture could be problematic in some population sectors, such as children, dementia patients, or subjects with vein problems (older adults, cancer patients...). Furthermore, the large volume of blood required for PBL isolation not only discourages collaborations in multidisciplinary research and limits the number of biomarkers that can be analysed in the sample volume obtained, but also makes it more likely that subjects refuse to participate (Cheng et al. 2001). For these reasons, optimizing and validating non-invasive cellular samples, such as epithelial exfoliated cells or salivary samples, may be crucial for human biomonitoring studies.

Due to its great versatility, the comet assay allows to explore the use of alternative cell types and tissues to assess DNA damage, such as buccal, nasal or bladder epithelial cells, placental cells, spermatozoa, and material from biopsies (Rojas et al. 2000; Augustowska et al. 2007; Ali et al. 2014; Azqueta et al. 2020). Among these alternative biomatrices, buccal samples and, in particular, salivary leucocytes, have a number of advantages, including a non-invasive collection, ease of processing, and interest for biomonitoring inhalatory or oral exposures. A recent review by the hComet network (researchers actively involved in the use of comet assay striving to improve the quality of the technique in studies on human exposures and diseases) addressed the key issues that are relevant in comet assay biomonitoring studies. They pointed out some problems regarding the use of salivary leucocytes, such as the number of cells retrieved per sample, the interference caused by the buccal epithelial cells on the comet images, and the consequent time-consuming analysis of the slides (Azqueta et al. 2020). Besides, the use of saliva samples as a source of leucocytes for the comet assay has not been standardized yet, and there are different aspects of this approach, such as its suitability to detect different kinds of DNA damage, both primary and oxidative, the possibility of using cryopreserved cells, or the comparison with the sensitivity obtained when employing PBL, that remain to be investigated.

On this basis, the objectives of this study were (i) to test the validity of salivary leucocytes as a proper biomatrix for the comet assay, (ii) to evaluate the ability of this approach to detect different types of primary and oxidative DNA damage, and (iii) to determine whether frozen salivary leucocytes are still suitable for displaying those types of DNA damage. To that aim, leucocytes isolated from saliva samples obtained from healthy volunteers, both fresh and frozen, were exposed to three concentrations of four wellknown genotoxic agents inducing different types of DNA damage. Primary and oxidative DNA damage were evaluated by means of the standard alkaline and 8-oxoguanine DNA glycosylase (hOGG1)-modified comet assay, respectively. Results were compared with those obtained from PBL (from the same donors), the sample type most frequently used in human biomonitoring studies.

\section{Materials and methods}

\section{Chemicals and reagents}

Actinomycin-D (Act-D) from Streptomyces sp. suitable for cell culture $\geq 95 \%$ (CAS number 50-76-0), dimethyl sulfoxide ACS reagent $\geq 99.9 \%$ (DMSO) (CAS number 67-68-5), Histopaque ${ }^{\circledR}-1077$ sterile-filtered, methyl methanesulfonate (MMS) 99\% (CAS number 66-27-3), potassium bromate $\left(\mathrm{KBrO}_{3}\right)$ for analysis EMSURE ${ }^{\circledR}$ Reag. Ph Eur (CAS number 7758-01-2), and 4',6-diamidine-2'-phenylindole (DAPI) (CAS No. 28718-90-3) were purchased from Sigma-Aldrich Co. (Merck KGaA, Darmstadt, Germany). Human 8-oxoguanine DNA glycosylase (hOGG1) was obtained from Trevigen Inc. (Gaithersburg, MD, USA). Act-D, MMS and $\mathrm{KBrO}_{3}$ were dissolved in sterile distilled water $\left(\mathrm{dH}_{2} \mathrm{O}\right)$.

\section{Sample collection and processing}

Six healthy non-smoking volunteers (four women and two men, aged between 25 and 46) participated in this study. The study followed ethical criteria established by the Helsinki declaration. Written consent was obtained from each donor prior to joining the study. Saliva samples were collected at 3 different times from each subject by performing four consecutive mouth rinses with $10 \mathrm{ml}$ of $0.9 \% \mathrm{NaCl}$ sterile solution for $1 \mathrm{~min}$ each. The four rinses were combined in sterile $50 \mathrm{ml}$ conical centrifuge tubes. No changes in the oral 
hygiene habits were attempted, but eating or drinking anything but water was not allowed in the hour before sampling.

The oral rinses from each participant $(\sim 40 \mathrm{ml})$ were centrifuged for $15 \mathrm{~min}$ at $1100 \times g$ and $4{ }^{\circ} \mathrm{C}$. The supernatant was carefully discarded, and cell pellet was re-suspended in $2 \mathrm{ml}$ phosphate-buffered saline solution (PBS). Cell suspensions from the six donors were then immediately pooled together in a sterile $15 \mathrm{ml}$ conical tube, and centrifuged for $15 \mathrm{~min}$ at $1100 \times g$ and $4{ }^{\circ} \mathrm{C}$. Then the cell pellet was resuspended in $8 \mathrm{ml}$ RPMI 1640 cell culture medium (Gibco, Thermo Fisher Scientific, Madrid, Spain). Leucocytes were isolated from the cell suspension by density gradient centrifugation using Histopaque ${ }^{\circledR}-1077$, following the manufacturer's instructions. Briefly, the cell suspension was carefully layered over $4 \mathrm{ml}$ Histopaque ${ }^{\circledR}-1077$, and centrifuged for $30 \mathrm{~min}$ at $400 \times g$, with brake turned off. The upper layer was gently withdrawn, leaving the interface (leucocytes) and cell pellet (epithelial cells) undisturbed. The interface was removed with a sterile Pasteur pipette, transferred to another tube with $5 \mathrm{ml} \mathrm{PBS}$, and centrifuged for $15 \mathrm{~min}$ at $1100 \times \mathrm{g}$.

One fraction of pooled leucocytes isolated from saliva was re-suspended in freezing medium [40\% RPMI 1640, $50 \%$ foetal bovine serum (FBS, Gibco, Thermo Fisher Scientific, Madrid, Spain), and 10\% DMSO] at $2.5 \times 10^{6}$ cells $/ \mathrm{ml}$ and frozen at $-80{ }^{\circ} \mathrm{C}$ into cryogenic vials, for at least 1 week. The remaining pooled leucocyte fraction was immediately used for treatments with the genotoxic agents, as described below.

Whole blood samples were obtained from the same volunteers by venepuncture, using BD Vacutainer ${ }^{\circledR} \mathrm{CPT}^{\mathrm{TM}}$ tubes with sodium heparin as anticoagulant (Becton Dickinson), and PBL were isolated following the manufacturer's instructions. The isolated PBL from each donor were washed with PBS, centrifuged ( $10 \mathrm{~min}, 1100 \times g$ at $4{ }^{\circ} \mathrm{C}$ ), and re-suspended in $100 \mu \mathrm{lBS}$. PBL from all donors were then pooled together and centrifuged at $4{ }^{\circ} \mathrm{C}$ and $1100 \times g$ for $10 \mathrm{~min}$. The pellet obtained was suspended in freezing medium containing 50\% FBS, 40\% RPMI 1640 and 10\% DMSO, at a concentration of $10^{7}$ cells $/ \mathrm{ml}$, and stored at $-80{ }^{\circ} \mathrm{C}$ until analysis (at least 1 week).

Figure 1 shows a complete overview of the experiments carried out.

\section{Treatments}

Frozen leucocytes from saliva and peripheral blood were quickly thawed at $37{ }^{\circ} \mathrm{C}$ and centrifuged at $1100 \times g$ for $15 \mathrm{~min}$. Fresh and frozen saliva leucocytes and frozen PBL were exposed to four well-known DNA damaging agents: MMS, Act-D, ultraviolet (UV) radiation, and $\mathrm{KBrO}_{3}$. The doses used, as well as the treatment times, were selected on the basis of previous studies (Collins et al. 1997; SánchezFlores et al. 2015; Laffon et al. 2017; Møller et al. 2020b).

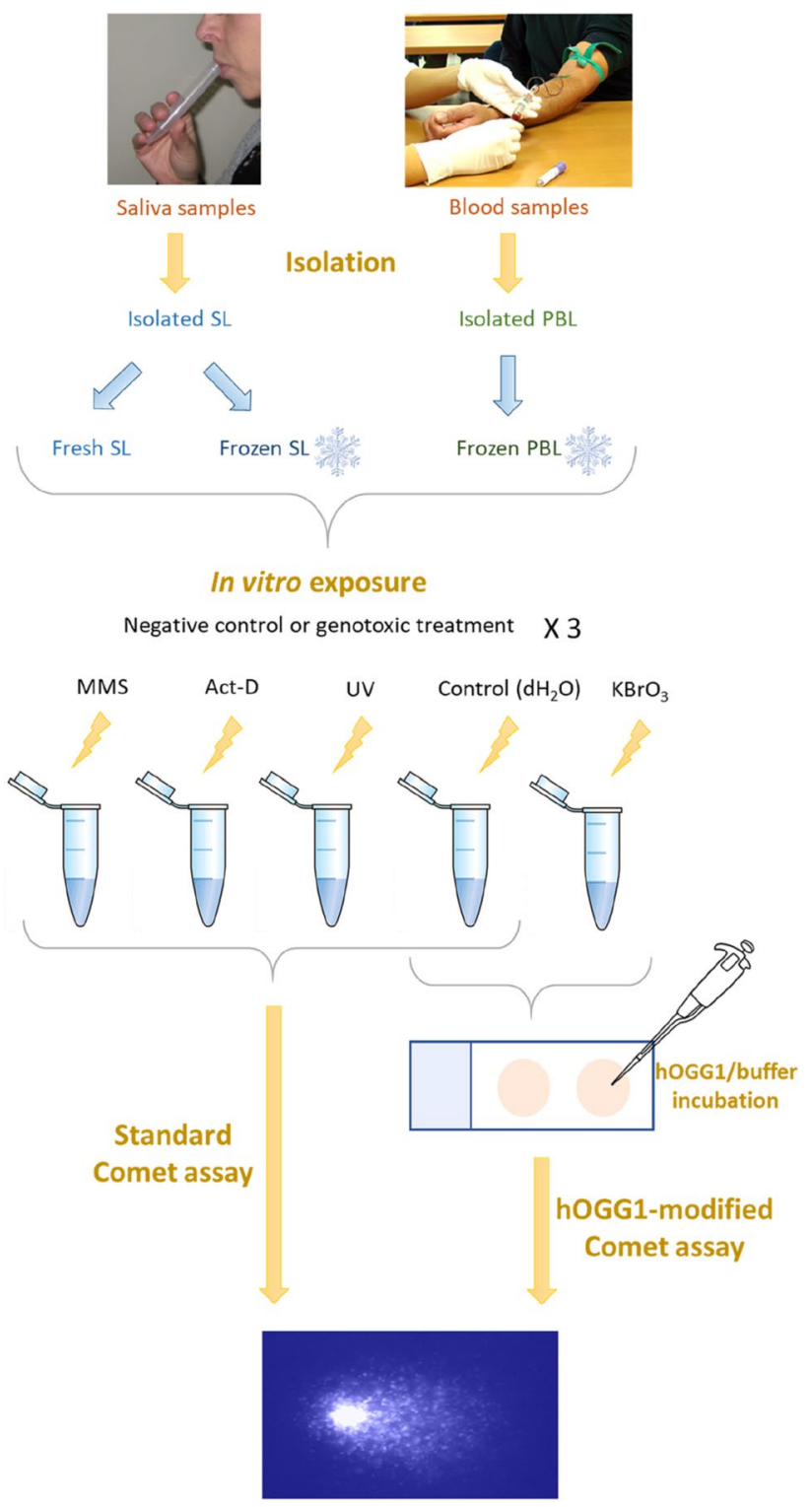

Fig. 1 Scheme of the study planning. Leucocytes were isolated from saliva and peripheral blood samples. Salivary leucocytes (SL) were used either fresh or after being cryopreserved. Peripheral blood leucocytes (PBL) were used after cryopreservation. Cells were exposed to methyl methanesulfonate (MMS), actinomycin-D (Act-D), ultraviolet (UV) light, or potassium bromate $\left(\mathrm{KBrO}_{3}\right)$, and distilled water $\left(\mathrm{dH}_{2} \mathrm{O}\right)$ was used as negative control. Then, cells were centrifuged and resuspended in low melting point agarose to conduct the standard alkaline comet assay (for MMS, Act-D and UV treatments) or the hOGG1-modified comet assay (for $\mathrm{KBrO}_{3}$ treatments)

Cells were treated at $37{ }^{\circ} \mathrm{C}$ with the specific genotoxic chemicals at three different concentrations (1\% of final volume in RPMI 1640): MMS 50, 75 and $100 \mu \mathrm{g} / \mathrm{ml}$ and Act-D 1,2 and $4 \mu \mathrm{g} / \mathrm{ml}$ for $3 \mathrm{~h}$; and $\mathrm{KBrO}_{3} 55,167$ and $334 \mu \mathrm{g} / \mathrm{ml}$ for $1 \mathrm{~h}$. Additionally, cells suspended in $1 \mathrm{ml}$ RPMI 1640 and placed in a 12 well-plate on ice were exposed to 300 , 500 and $700 \mu \mathrm{J} / \mathrm{cm}^{2} \mathrm{UV}$ radiation pulses $(254 \mathrm{~nm})$, in an 
Analytik Jena AG UVP CL-1000 crosslinker (Cultek S.L.U, Madrid, Spain). After irradiation, leucocytes were kept at $37^{\circ} \mathrm{C}$ for $1 \mathrm{~h}$, time necessary to reach the maximum damage expression, according to previous experiments (Valdiglesias et al. 2020). Negative controls $\left(\mathrm{dH}_{2} \mathrm{O}\right)$ were included in each experiment. Cell viability was checked after treatments by trypan blue exclusion technique, resulting higher than $80 \%$ in all cases.

\section{Alkaline comet assay}

Minimum Information for Reporting Comet Assay procedures and results (MIRCA) recommendations were followed in this manuscript (Møller et al. 2020a). After MMS, Act-D and UV treatments, primary DNA damage was assessed by the standard alkaline comet assay. Immediately after treatments, cell suspensions were centrifuged at $8700 \times g$ for $3 \mathrm{~min}$ and, after removing the supernatant, the remaining cell suspension $(20 \mu \mathrm{l})$ was mixed with $0.9 \%$ low-meltingpoint agarose $(80 \mu \mathrm{l}$, freshly prepared). This suspension (final agarose concentration $0.72 \%$ ) was placed as two drops of $40 \mu \mathrm{l}$ on a slide previously coated with a layer of $1 \%$ normal melting point agarose. The drops were covered with $20 \times 20 \mathrm{~mm}$ coverslips and slides were placed on ice for 15 min to allow agarose solidification. After removing the coverslips, lysis was conducted by immersing the slides in lysis solution (100 mM Na 2 EDTA, $250 \mathrm{mM} \mathrm{NaOH}, 2.5 \mathrm{M}$ $\mathrm{NaCl}, 10 \mathrm{mM}$ Tris-HCl, $\mathrm{pH} 10$, and $1 \%$ Triton X-100 added just before use) at $4{ }^{\circ} \mathrm{C}$ overnight in the dark. Slides were positioned on a horizontal electrophoresis tank in an ice bath, and incubation for DNA unwinding was carried out for $20 \mathrm{~min}$ in the dark in cold $\left(4{ }^{\circ} \mathrm{C}\right)$ freshly made alkaline electrophoresis solution $\left(1 \mathrm{mM} \mathrm{Na}{ }_{2} \mathrm{EDTA}, 300 \mathrm{mM} \mathrm{NaOH}\right.$, $\mathrm{pH}>13$ ). Electrophoresis was then conducted at $0.83 \mathrm{~V} / \mathrm{cm}$ for $20 \mathrm{~min}$. Slides were washed with neutralizing solution (0.4 M Tris- $\mathrm{HCl}, \mathrm{pH} 7.5) 3$ times $\times 5$ min, and air-dried in the dark at room temperature. Afterwards, preparations were stained with $5 \mu \mathrm{g} / \mathrm{ml}$ DAPI ( $25 \mu \mathrm{l}$ per drop) for at least 30 min before scoring. To prevent drying of the gel, slides were kept in a humidified sealed box at $4{ }^{\circ} \mathrm{C}$, and analysed within 6 days.

Image capture and analysis were performed using the Comet IV software (Perceptive Instruments). In all cases, 100 cells in total (i.e., 50 cells from each replicate) were scored using a magnification of $40 \times$ by the same "blind" scorer, and the percentage of DNA in the comet tail (\%tDNA) was used as DNA damage parameter.

\section{hOGG1-modified comet assay}

After $\mathrm{KBrO}_{3}$ treatments, oxidative DNA damage was evaluated by means of the hOGG1-modified comet assay. Duplicate slides with two agarose drops per slide were prepared for each experimental condition. After the lysis step in the standard alkaline comet assay, slides were washed 3 times for $5 \mathrm{~min}$ each with enzyme buffer $(0.5 \mathrm{mM}$ EDTA, $0.2 \mathrm{mg} /$ $\mathrm{ml}$ bovine serum albumin, $0.1 \mathrm{M} \mathrm{KCl}, 40 \mathrm{mM}$ Hepes, $\mathrm{pH}$ 8.0). Then, slides were split into two groups and treated with either $50 \mu \mathrm{l}$ hOGG1 ( $0.0016 \mathrm{U} / \mu \mathrm{l}$ buffer) or $50 \mu \mathrm{l}$ buffer per condition, covered with $20 \times 20$ coverslips, and incubated at $37^{\circ} \mathrm{C}$ for $30 \mathrm{~min}$ in a humidified box. After this incubation, slides were processed as in the standard alkaline comet assay (described in the previous section). Net hOGG1-sensitive sites were calculated by subtracting the \%tDNA obtained after buffer incubation from that obtained after the enzyme incubation for each experimental condition.

\section{Statistical analysis}

A minimum of three independent experiments (two in the case of $\mathrm{KBrO}_{3}$ treated samples, due to the lockdown restrictions motivated by the COVID-19 pandemic) were performed for each experimental condition tested, and each condition was always run in duplicate. Experimental data were expressed as mean \pm standard error. Differences among groups (all concentrations tested under the same conditions) were analysed with Kruskal-Wallis test. Two-by-two comparisons were evaluated with Mann-Whitney $U$-test. Dose-response relationships were evaluated by Spearman's correlation. A $P$-value $<0.05$ was considered significant. Statistical analyses were performed using SPSS for Windows statistical package V. 21.

\section{Results}

In this paper suitability of salivary leucocytes to be used as cell sample for the comet assay was tested, as well as the possibility to freeze these samples, and results were compared with those from PBL, the most extensively used cell type for the comet assay when applied to human biomonitoring studies. To determine whether this approach is valid for detecting different types of DNA damage, salivary leucocytes and PBL were exposed to genotoxic agents with different action mechanisms: MMS, Act-D, UV radiation and $\mathrm{KBrO}_{3}$. Since there is evidence to suggest that PBL can be cryopreserved for several years without much effect on the level of DNA damage (reviewed in Møller et al. 2021), frozen PBL were used in this study as the gold standard for comparison purposes.

Figure 2 shows the results obtained in the standard comet assay for MMS treatments. The three doses tested induced highly significant increases in DNA damage in all sample types used. Dose-effect relationships were significant in all sample types $(r=0.860, P<0.01$ for fresh 
MMS

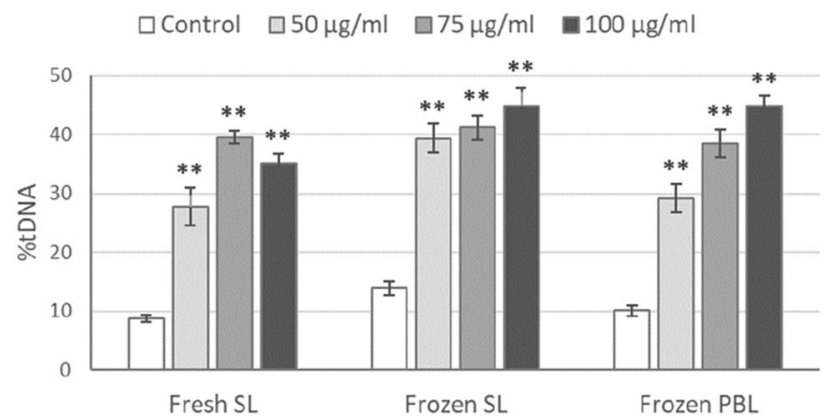

Fig. 2 Primary DNA damage induced by methyl methanesulfonate (MMS) in fresh and frozen salivary leucocytes (SL) and frozen peripheral blood leucocytes (PBL). Bars represent mean standard error. $* * P<0.01$, significant difference with regard to the corresponding control

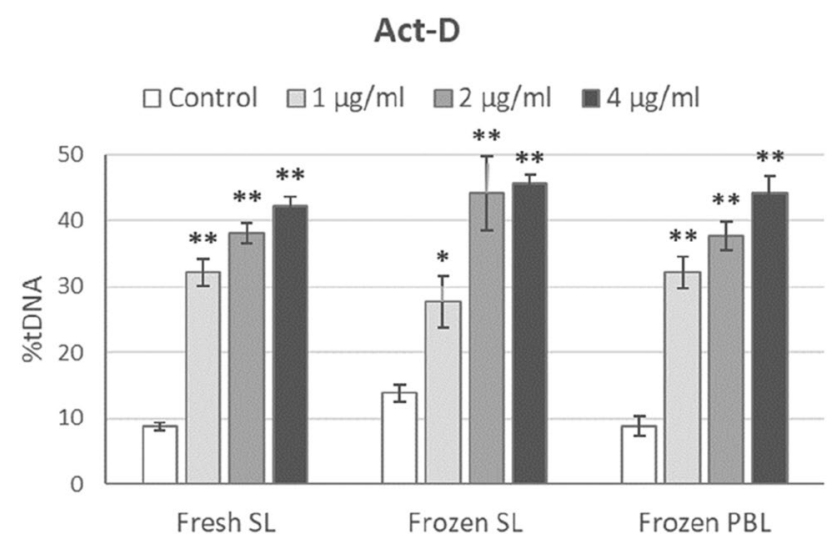

Fig. 3 Primary DNA damage induced by actinomycin-D (Act-D) in fresh and frozen salivary leucocytes (SL) and frozen peripheral blood leucocytes (PBL). Bars represent mean standard error. ${ }^{*} P<0.05$, $* * P<0.01$, significant difference with regard to the corresponding control

salivary leucocytes; $r=0.846, P<0.01$ for frozen salivary leucocytes; and $r=0.915, P<0.01$ for PBL).

The results from the standard comet assay conducted with cells treated with Act-D are depicted in Fig. 3. Significant and progressive increases in \%tDNA were obtained in both salivary leucocytes and PBL, and dose-response relationships were also significant in all cases $(r=0.911$, $P<0.01$ for fresh salivary leucocytes; $r=0.821, P<0.01$ for frozen salivary leucocytes; and $r=0.906, P<0.01$ for PBL).

Exposure of the cells to the three UV radiation doses assayed induced significant rises in the primary DNA damage (Fig. 4). Increases were progressive in frozen samples; fresh salivary leucocytes reached the maximum DNA damage at the intermediate dose $\left(500 \mu \mathrm{J} / \mathrm{cm}^{2}\right)$. Correlation analyses demonstrated good dose-effect relationships $(r=0.856$,

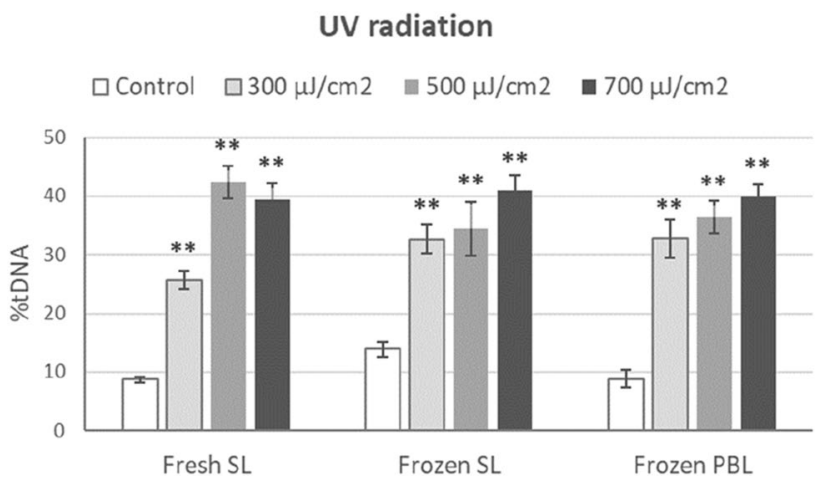

Fig. 4 Primary DNA damage induced by ultraviolet (UV) radiation in fresh and frozen salivary leucocytes (SL) and frozen peripheral blood leucocytes (PBL). Bars represent mean standard error. $* * P<0.01$, significant difference with regard to the corresponding control

$\mathrm{KBrO}_{3}$

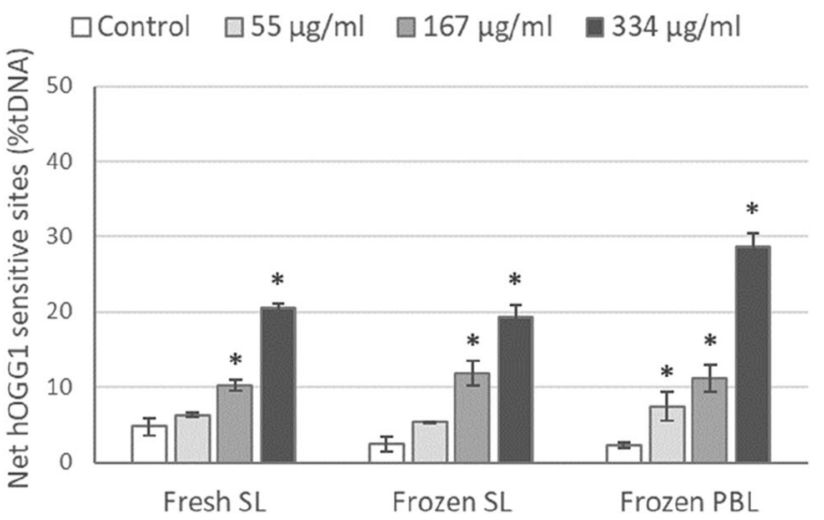

Fig. 5 hOGG1-modified comet assay results after treating fresh and frozen salivary leucocytes (SL) and frozen peripheral blood leucocytes (PBL) with potassium bromate $\left(\mathrm{KBrO}_{3}\right)$. Bars represent mean standard error. $* P<0.05$, significant difference with regard to the corresponding control

$P<0.01$ for fresh salivary leucocytes; $r=0.864, P<0.01$ for frozen salivary leucocytes; and $r=0.849, P<0.01$ for PBL).

Figure 5 shows data obtained from the hOGG1-modified comet assay carried out with cells treated with $\mathrm{KBrO}_{3}$, which mainly induces oxidative DNA damage (Møller et al. 2018). Although only two independent experiments were conducted, inter-experiment variability was low. Exposure caused significant increases in the net hOGG1 sensitive sites for the two highest doses tested ( 167 and $334 \mu \mathrm{g} / \mathrm{ml})$ in the three sample types, with a slight non-significant increase for the lowest dose $(55 \mu \mathrm{g} / \mathrm{ml})$. Dose-response relationships were significant in all cases $(r=0.912, P<0.01$ for fresh salivary leucocytes; $r=0.930, P<0.01$ for frozen salivary leucocytes; and $r=0.899, P<0.01$ for PBL).

Comparisons among basal genetic damage observed in the three sample types assayed are shown in Fig. 6. Although 


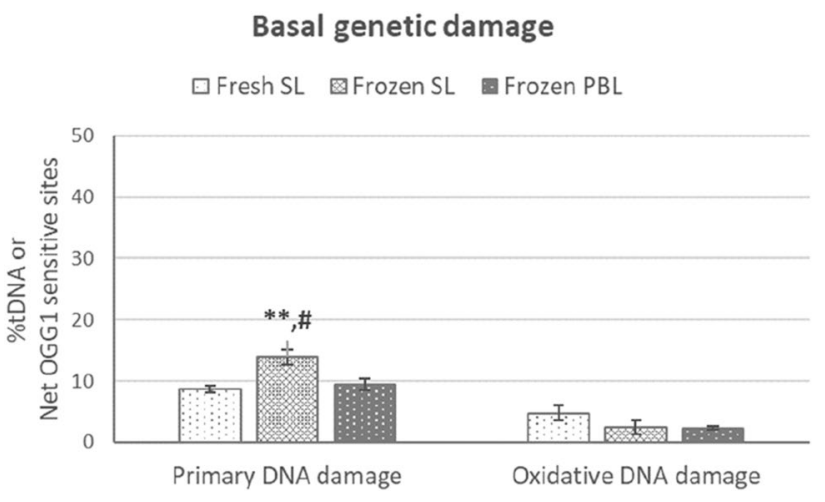

Fig. 6 Comparison between basal genetic damage (primary and oxidative) in negative controls $\left(\mathrm{dH}_{2} \mathrm{O}\right)$ used for all the sample types tested in this study. SL: salivary leucocytes. ${ }^{*} * P<0.01$, significant difference with regard to fresh $\mathrm{SL} ;{ }^{\#} P<0.05$, significant difference with regard to frozen PBL

no differences were observed regarding the oxidative DNA damage, background primary DNA damage as evaluated by the standard comet assay was significantly higher in the frozen salivary leucocytes than in the same fresh cell type and in frozen PBL.

\section{Discussion}

Comet assay is a worldwide extended biomonitoring tool to examine the effects of dietary, lifestyle, environmental and occupational exposures on levels of DNA damage in single cells (Azqueta et al. 2020). Leucocytes isolated from blood samples (PBL) have been traditionally used in this approach to investigate DNA damage in population studies, but alternative cell samples need to be investigated to improve the usefulness of this assay in human biomonitoring. Indeed, the potential applicability of the comet assay to almost any cell type confers an important advantage in exploring the use of other biomatrices, such as exfoliated epithelial cells-buccal, nasal, lens, corneal (Rojas et al. 2014), and bladder cells (Cavallo et al. 2014), germ cells (Ali et al. 2014), different eye tissues (Azqueta et al. 2018), or biopsies (Lundby et al. 2003).

Among these biomatrices, cells from the buccal cavity are obtained non-invasively, facilitating acceptance by most subjects; consequently, they have been proposed as an alternative strategy in human population studies using the comet assay (Szeto et al. 2005; Rojas et al. 2014). Besides, they may reflect the effect of early oral or respiratory exposures, which makes them particularly interesting for biomonitoring. Buccal cell populations consist not only of epithelial cells from the oral cheek mucosa, but also of leucocytes, fibroblasts and erythrocytes (Yamamoto et al. 1991; Oßwald et al. 2003). Hence, it can be expected that these different cell types have different viabilities and highly varied biotransformation systems, and thus are unequally susceptible to risk factors. The relative proportions of viable and non-viable buccal cells, as obtained by mouthwashes, were previously determined (Oßwald et al. 2003). Erythrocytes and fibroblasts were extremely rare with a presence of less than $1 \%$ each, whereas the proportions of exfoliated buccal epithelial cells and leucocytes were majority and approximately equal. Due to their specific features, buccal epithelial cells need additional protocol steps that make the methodology more complex and subject to additional variability. In this scenario, salivary leucocytes seem a very convenient cell type to replace or complement blood samples in human biomonitoring. They join the advantages of leucocytes [i.e., easily obtained in large numbers, do not require cell culture, diploid, and almost all in the same phase of the cell cycle $\left.\left(\mathrm{G}_{0}\right)\right]$ (Collins et al. 2008), with the non-invasive sampling, thus facilitating collection in sensitive individuals.

Thus, salivary leucocytes were previously used in comet assay biomonitoring studies. McCauley et al. (2008) found increased DNA damage in salivary leucocytes (isolated by density gradient centrifugation) of agricultural workers compared to controls. And Zani et al. (2020) evaluated the effects of air pollution in salivary leucocytes (directly obtained from mouthwashes, without isolation) of exposed pre-school children, observing no significant association between air pollution and DNA damage. Furthermore, although buccal leucocytes obtained from smokers and analysed by the comet assay were reported to have more DNA damage than cells from non-smokers (Oßwald et al. 2003), more recent studies showed that comet parameters evaluated in salivary leucocytes are not influenced by sex, age, smoking habit, diet, alcohol consumption or body mass index (McCauley et al. 2008; Russo et al. 2020). All these studies demonstrate the feasibility of using salivary leucocytes in the comet assay for human population studies. Still, and despite them, the technique has not been standardized yet, leading to great variability among studies and preventing extensive use of the assay. Besides, the possibility of employing frozen samples, particularly relevant in epidemiological studies in which large numbers of samples are managed in short time, has not been previously addressed. On this basis, the present study was aimed to investigate the validity of fresh and frozen leucocytes isolated from saliva samples as a proper biomatrix for the comet assay, both in the standard and hOGG1-modified versions.

Three well-known genotoxic agents, i.e., MMS, Act-D, and UV light, were employed in the present study to address the suitability of fresh and frozen salivary leucocytes to respond to different types of primary DNA damage and be detected by means of the standard comet assay. MMS is an alkylating compound used for many years as a DNA damaging agent to induce mutagenesis and in recombination 
experiments. MMS methylates DNA bases, essentially guanine and, to a lesser extent, adenine (Beranek 1990). MMS-induced lesions are considered a source of DNA double strand breaks as a result of collapsed replication forks at the lesions or processed intermediates (Ma et al. 2011). Act-D is an anti-tumour drug that particularly intercalates into transcriptionally active regions of chromosomal DNA and thereby abrogates RNA synthesis (Sobell 1985), leading to formation of DNA single and double strand breaks (Sánchez-Flores et al. 2015; Laffon et al. 2021). Finally, UV light is the most pervasive environmental DNA-damaging agent (Jackson and Bartek 2009). In particular, UV radiation induces 6-4 photoproducts and cyclobutane pyrimidine dimers in DNA which are repaired by nucleotide excision repair pathway (Wei et al. 2005). In all cases, cells exposed to these three genotoxic agents showed dose-dependent increases of primary DNA damage, regardless the cell sample employed, demonstrating the sensitivity of all these samples to the induction of genetic damage from different origin and their suitability for the comet assay procedure. Besides, response of the different biomatrices, i.e., salivary leucocytes, both fresh and frozen, and frozen PBL, to the three types of genetic insults was quite similar to one another, and consistent with a number of previous studies evaluating the effects of the same genotoxic agents on different cell types (Collins et al. 1997; Laffon et al. 2017; Valdiglesias et al. 2020). Furthermore, comparing the baseline level of primary DNA damage (Fig. 6), no differences were observed between fresh salivary leucocytes and PBL, and frozen salivary cells showed just a slight significant increase in basal genetic damage regarding the other biomatrices. Still, the similar results regarding sensitivity to DNA damage induction by the three different agents-MMS, Act-D and UV lightobtained in the three sample types support the possibility of using salivary leucocytes as a good alternative or complement to blood samples. According to these results, Russo et al. (2020) compared recently the basal level of primary DNA damage in salivary leucocytes and isolated PBL (both freshly obtained) from 15 young subjects, to found that the two sample types provide similar measures, as the level of agreement (calculated by the Bland-Altman method) lied within the accepted range.

Oxidative stress is a phenomenon caused by an imbalance between production and accumulation of reactive oxygen species (ROS) in cells and tissues and the ability of a biological system to detoxify these reactive products (Pizzino et al. 2017). A number of agents may contribute to increase ROS production causing the imbalance that leads to cell and tissue damage, including genetic injury. Comet assay may be used to assess oxidative stress-induced genotoxicity by introducing an additional step of incubation with some lesion-specific endonucleases. The human 8-oxoguanine DNA glycosylase (hOGG1) is the most effective enzyme in specifically detecting 8-oxo-7,8-dihydroguanine (8-oxoGua), the most frequent DNA oxidative lesion, since unlike formamidopyrimidine glycosylase (fpg) or endonuclease III (endoIII) it does not recognize alkylated bases (Smith et al. 2006); therefore, it appears to give more reliable estimates of DNA oxidation damage (Muruzabal et al. 2021). hOGG1-modified comet assay has been widely used in human biomonitoring studies to detect oxidative DNA damage (Azqueta et al. 2020). As it was previously described (Møller et al. 2018), $\mathrm{KBrO}_{3}$ causes oxidative damage to bases but do not generate DNA strand breaks, demonstrating that it is a suitable positive control for the enzyme-modified comet assay (Møller et al. 2020b). Besides, $\mathrm{KBrO}_{3}$ is known to induce hOGG1sensitive sites (Smith et al. 2006; Pfuhler et al. 2017). On this basis, in the present study, the validity of leucocytes isolated from saliva samples (both fresh and frozen) as proper biomatrices for the hOGG1-modified comet assay was also assessed by treating these cells with $\mathrm{KBrO}_{3}$. Similarly to primary DNA damage evaluation, results obtained from the three cell samples analysed resulted quite similar. In particular, exposure to $\mathrm{KBrO}_{3}$ caused significant increases in the net hOGG1 sensitive sites for the two highest doses tested, with a slight non-significant increase for the lowest dose. Dose-response relationships were significant in all cases. Regarding the baseline level of oxidative DNA damage, no differences were observed among the three biomatrices, confirming that the freezing procedure do not induce additional oxidative DNA damage in these cells. A recent study also found that the response of PBL to oxidative damage induction (by $\mathrm{H}_{2} \mathrm{O}_{2}$ ) remained unaltered with freezing (Ladeira et al. 2019); however, the authors highlighted that these basal levels of oxidative DNA damage could be influenced by the time of cryopreservation, becoming significant after long cryopreservation periods (Del Bo' et al. 2015).

As it was confirmed in the current study, previously reported interference in the comet images caused by the buccal epithelial cells when evaluating salivary leucocytes (Azqueta et al. 2020) can be avoided by isolating the leucocytes contained in the saliva samples. Although recovery of leucocytes when isolated from mouthwashes by density gradient centrifugation was reported to be low (22\%), purity and cell viability of the isolated cells were high $(95 \%$ and $88 \%$, respectively) (Oßwald et al. 2003), and the quantity of cells obtained is enough for conducting the comet assay for biomonitoring purposes.

\section{Conclusions}

To conclude, in this study, the suitability of fresh and frozen salivary leucocyte samples to be employed as biomatrices to detect primary and oxidative DNA damage from different origin by the comet assay was successfully demonstrated, 
and resulted comparable to the gold standard cell sample for this assay (PBL). Consequently, salivary leucocytes can be employed in biomonitoring studies as an alternative or complement to blood samples, which are obtained by an invasive procedure and recommended to be avoided in some particular situations (children, older adults with dementia, patients with vein problems...). Furthermore, frozen salivary leucocytes were proved to be suitable for comet assay biomonitoring studies, and sensitive to the induction of different types of DNA damage, indicating they are a very convenient sample for antigenotoxicity studies or for assessing DNA repair capacity. Even though some additional basal damage was observed in frozen cells regarding fresh samples, similar results were obtained in the three sample types regarding sensitivity to DNA damage induction by different kinds of genetic insults. This fact demonstrates that isolation and freezing procedures of salivary leucocytes do not affect the sensitivity of these cells to the induction of DNA damage, both primary and oxidative.

Funding This work was supported by Xunta de Galicia [ED431B 2019/02] and Ministerio de Educación, Cultura y Deporte [BEAGAL18/00142 to V.V.]. The authors would also like to acknowledge the contribution of the hCOMET CA15132 COST Action.

\section{Declarations}

Conflict of interest The authors declare that they have no conflict of interest.

Ethical approval The manuscript does not contain clinical studies or patient data.

Informed consent All volunteers gave their informed consent prior to their inclusion in the study.

\section{References}

Ali A, Kurzawa-Zegota M, Najafzadeh M et al (2014) Effect of drinking water disinfection by-products in human peripheral blood lymphocytes and sperm. Mutat Res Rev Mutat Res 770:136-143. https://doi.org/10.1016/j.mrfmmm.2014.08.003

Augustowska K, Magnowska Z, Kapiszewska M, Gregoraszczuk EL (2007) Is the natural PCDD/PCDF mixture toxic for human placental JEG-3 cell line? The action of the toxicants on hormonal profile, CYP1A1 activity, DNA damage and cell apoptosis. Hum Exp Toxicol 26:407-417. https://doi.org/10.1177/0960327107 073119

Azqueta A, Collins AR (2013) The essential comet assay: a comprehensive guide to measuring DNA damage and repair. Arch Toxicol 87:949-968. https://doi.org/10.1007/s00204-013-1070-0

Azqueta A, Rundén-Pran E, Elje E et al (2018) The comet assay applied to cells of the eye. Mutagenesis 33:21-24. https://doi.org/10.1093/ mutage/gex 025

Azqueta A, Ladeira C, Giovannelli L et al (2020) Application of the comet assay in human biomonitoring: an hCOMET perspective.
Mutat Res Rev Mutat Res 783:108288. https://doi.org/10. 1016/j.mrrev.2019.108288

Beranek DT (1990) Distribution of methyl and ethyl adducts following alkylation with monofunctional alkylating agents. Mutat Res Fundam Mol Mech Mutagen 231:11-30. https://doi.org/ 10.1016/0027-5107(90)90173-2

Cavallo D, Casadio V, Bravaccini S et al (2014) Assessment of DNA damage and telomerase activity in exfoliated urinary cells as sensitive and noninvasive biomarkers for early diagnosis of bladder cancer in ex-workers of a rubber tyres industry. Biomed Res Int 2014:1-8. https://doi.org/10.1155/2014/370907

Cheng L, Wang LE, Spitz MR, Wei Q (2001) Cryopreserving whole blood for functional assays using viable lymphocytes in molecular epidemiology studies. Cancer Lett 166:155-163. https://doi. org/10.1016/S0304-3835(01)00400-1

Collins AR (2004) The comet assay for DNA damage and repair: principles, applications, and limitations. Mol Biotechnol 26:249-261. https://doi.org/10.1385/MB:26:3:249

Collins AR, Dobson VL, Dušinská M et al (1997) The comet assay: what can it really tell us? Mutat Res Fundam Mol Mech Mutagen 375:183-193. https://doi.org/10.1016/S0027-5107(97) 00013-4

Collins AR, Oscoz AA, Brunborg G et al (2008) The comet assay: topical issues. Mutagenesis 23:143-151. https://doi.org/10. 1093/mutage/gem051

Collins A, Koppen G, Valdiglesias V et al (2014) The comet assay as a tool for human biomonitoring studies: the comnet project. Mutat Res Mutat Res 759:27-39. https://doi.org/10.1016/j. mrrev.2013.10.001

Del Bo C, FracassettiLanti DC et al (2015) Comparison of DNA damage by the comet assay in fresh versus cryopreserved peripheral blood mononuclear cells obtained following dietary intervention. Mutagenesis 30:29-35. https://doi.org/10.1093/ mutage/geu058

Jackson SP, Bartek J (2009) The DNA-damage response in human biology and disease. Nature 461:1071-1078. https://doi.org/10. 1038/nature08467

Ladeira C, Koppen G, Scavone F, Giovannelli L (2019) The comet assay for human biomonitoring: Effect of cryopreservation on DNA damage in different blood cell preparations. Mutat Res Genet Toxicol Environ Mutagen 843:11-17. https://doi.org/10. 1016/j.mrgentox.2019.02.002

Laffon B, et al (2021) Applicability of flow cytometry $\gamma \mathrm{H} 2 \mathrm{AX}$ assay in population studies: suitability of fresh and frozen whole blood samples. Arch Toxicol (in press)

Laffon B, Fernández-Bertólez N, Costa C et al (2017) Comparative study of human neuronal and glial cell sensitivity for in vitro neurogenotoxicity testing. Food Chem Toxicol 102:120-128. https:// doi.org/10.1016/j.fct.2017.02.005

Lundby C, Pilegaard H, Van Hall G et al (2003) Oxidative DNA damage and repair in skeletal muscle of humans exposed to highaltitude hypoxia. Toxicology 192:229-236. https://doi.org/10. 1016/S0300-483X(03)00328-7

Ma W, Westmoreland JW, Gordenin DA, Resnick MA (2011) Alkylation base damage is converted into repairable double-strand breaks and complex intermediates in G2 cells lacking AP endonuclease. PLoS Genet 7:e1002059. https://doi.org/10.1371/journal.pgen. 1002059

McCauley L, Lasarev M, Muniz J et al (2008) Analysis of pesticide exposure and DNA damage in immigrant farmworkers. J Agromedicine 13:237-246. https://doi.org/10.1080/105992408024738 17

Møller P, et al (2021) Collection and storage of human white blood cells for analysis of DNA damage and repair activity using the comet assay in molecular epidemiology studies. Mutagenesis (in press) 
Møller P, Jantzen K, Løhr M et al (2018) Searching for assay controls for the Fpg- and hOGG1-modified comet assay. Mutagenesis 33:9-19. https://doi.org/10.1093/mutage/gex015

Møller P, Azqueta A, Boutet-Robinet E et al (2020a) Minimum information for reporting on the comet assay (MIRCA): recommendations for describing comet assay procedures and results. Nat Protoc 15:3817-3826. https://doi.org/10.1038/s41596-020-0398-1

Møller P, Muruzabal D, Bakuradze T et al (2020b) Potassium bromate as positive assay control for the Fpg-modified comet assay. Mutagenesis 35:341-348. https://doi.org/10.1093/mutage/geaa011

Muruzabal D, Collins A, Azqueta A (2021) The enzyme-modified comet assay: Past, present and future. Food Chem Toxicol 147:111865. https://doi.org/10.1016/j.fct.2020.111865

Oßwald K, Mittas A, Glei M, Pool-Zobel BL (2003) New revival of an old biomarker: characterisation of buccal cells and determination of genetic damage in the isolated fraction of viable leucocytes. Mutat Res Rev Mutat Res 544:321-329. https://doi.org/10.1016/j. mrrev.2003.06.008

Pfuhler S, Downs TR, Allemang AJ et al (2017) Weak silica nanomaterial-induced genotoxicity can be explained by indirect DNA damage as shown by the OGG1-modified comet assay and genomic analysis. Mutagenesis 32:5-12. https://doi.org/10.1093/mutage/ gew064

Pizzino G, Irrera N, Cucinotta M et al (2017) Oxidative stress: harms and benefits for human health. Oxid Med Cell Longev 2017:1-13. https://doi.org/10.1155/2017/8416763

Rojas E, Lopez MC, Valverde M (1999) Single cell gel electrophoresis assay: methodology and applications. J Chromatogr B Biomed Sci Appl 722:225-254. https://doi.org/10.1016/S0378-4347(98) 00313-2

Rojas E, Valverde M, Lopez MC et al (2000) Evaluation of DNA damage in exfoliated tear duct epithelial cells from individuals exposed to air pollution assessed by single cell gel electrophoresis assay. Mutat Res Genet Toxicol Environ Mutagen 468:11-17. https://doi.org/10.1016/S1383-5718(00)00035-8

Rojas E, Lorenzo Y, Haug K et al (2014) Epithelial cells as alternative human biomatrices for comet assay. Front Genet 5:1-1. https:// doi.org/10.3389/fgene.2014.00386

Russo C, Acito M, Fatigoni C et al (2020) B-comet assay (comet assay on buccal cells) for the evaluation of primary dna damage in human biomonitoring studies. Int J Environ Res Public Health 17:1-14. https://doi.org/10.3390/ijerph17249234

Sánchez-Flores M, Pásaro E, Bonassi S et al (2015) $\gamma \mathrm{H} 2 \mathrm{AX}$ assay as DNA damage biomarker for human population studies: defining experimental conditions. Toxicol Sci 144:406-413. https://doi. org/10.1093/toxsci/kfv011

Smith CC, O'Donovan MR, Martin EA (2006) hOGG1 recognizes oxidative damage using the comet assay with greater specificity than FPG or ENDOIII. Mutagenesis 21:185-190. https://doi.org/ 10.1093/mutage/gel019

Sobell HM (1985) Actinomycin and DNA transcription. Proc Natl Acad Sci USA 82:5328-5331. https://doi.org/10.1073/pnas.82. 16.5328

Szeto YT, Benzie IFF, Collins AR et al (2005) A buccal cell model comet assay: development and evaluation for human biomonitoring and nutritional studies. Mutat Res Fundam Mol Mech Mutagen 578:371-381. https://doi.org/10.1016/j.mrfmmm.2005.06.014

Szeto YT, Lee AKH, Benzie IFF, Obied HK (2012) Optimized noninvasive procedures to measure DNA damage in comet assay. Hum Exp Toxicol 31:1144-1150. https://doi.org/10.1177/0960327112 446816

Valdiglesias V, Sánchez-Flores M, Fernández-Bertólez N et al (2020) Expanded usage of the challenge-comet assay as a DNA repair biomarker in human populations: protocols for fresh and cryopreserved blood samples, and for different challenge agents. Arch Toxicol 94:4219-4228. https://doi.org/10.1007/ s00204-020-02881-5

Wei Z, Lifen J, Jiliang H et al (2005) Detecting DNA repair capacity of peripheral lymphocytes from cancer patients with UVC challenge test and bleomycin challenge test. Mutagenesis 20:271-277. https://doi.org/10.1093/mutage/gei037

Yamamoto M, Saeki K, Utsumi K (1991) Isolation of human salivary polymorphonuclear leukocytes and their stimulation-coupled responses. Arch Biochem Biophys 289:76-82. https://doi.org/10. 1016/0003-9861(91)90444-N

Zani C, Ceretti E, Zerbini I et al (2020) Comet test in saliva leukocytes of pre-school children exposed to air pollution in north Italy: the respira study. Int J Environ Res Public Health 17:3276. https://doi. org/10.3390/ijerph17093276

Publisher's Note Springer Nature remains neutral with regard to jurisdictional claims in published maps and institutional affiliations. 